\title{
Concentrated Ownership Structure and Audit Quality: New Evidence from Nigeria
}

\author{
A. Akinwunmi, S. Dada, A. Ajayi-Owoeye and J. Kwarbai
}

\begin{abstract}
Shareholders with a large stake in a company may have greater incentives to monitor and take corrective actions, because they partially internalize the benefits from their monitoring effort. This study examined the impact of concentrated ownership on audit quality as measured by auditors' tenure of $\mathbf{3 6}$ manufacturing companies quoted on the NSE. The sample size was selected using non-probability method of sampling from a population of 185 quoted companies on the Nigerian Stock Exchange. The study adopted experimental research design and secondary data extracted from the audited annual reports of the firms under consideration covering a period 2007 to 2017 was used. The study found that ownership concentration has no statistically significant impact on auditors' tenure. The study therefore recommends that ownership concentration should be maintained at a controllable level; the insignificant impact of concentrated ownership on auditors' tenure as evident in this study might be the result of inefficient monitoring by large owners. But when ownership concentration by large ownership is maintained at a controlling level, firm values and other performance parameters become positive which may be as a result of an effective internal control system against the expropriation of resources and exploitation of minority shareholders by large shareholders.
\end{abstract}

Index Terms - Auditors' tenure, Concentrated ownership, Expropriation, Minority shareholders, Monitoring.

\section{INTRODUCTION}

Empirically, the impact of ownership concentration on the corporate wellbeing is still indecisive in the developed and developing nations. A review of the extant literature suggests that it is of paramount importance to carry out a further examination of the role of concentrated ownership in setting up an effective corporate governance structure in business organisations. Concentrated ownership structure and its attendant impact on different companies' performance constructs among developing economies nascent markets has been described as one of the imperative matters of governance structure [1]. Ownership concentration may exert positive impacts in organization by improving the monitoring and also eliminating false financial reporting.

While other mechanisms may prove otherwise According to Reference [2], Ownership concentration will motivate important stockholders to take up greater investment in the

Published on June 17, 2020.

A. Akinwunmi, Babcock University, Nigeria.

(e-mail: akinabiodun@yahoo.com)

O. Dada, Babcock University, Nigeria.

(e-mail: erinpe@yahoo.com)

A. Ajayi-Owoeye, Babcock University, Nigeria

J. Kwarbai, Babcock University, Nigeria.

(e-mail: kwarbai.jerry@gmail.com) company in order to gain better management controls. A further study by Reference [1] suggests that if shareholders ownership is more concentrated, this will motivate them to take up more shares in order to have a better control on company's managers thereby reducing agency problem. Furthermore, Reference [3] argues that high concentration can serve as a sincere assurance made by controlling shareholders toward a character of not appropriating the interests of non-controlling shareholders. The inference, therefore, is that concentrated ownership structure may encourage the controlling shareholders to willingly disclose more and improved firm-specific information for the benefit of non-controlling minority. Reference [4] show that firms with more concentrated ownership structure are less likely to use Big 4 auditors than non-family firms or firms with less-concentrated ownership. Similarly, Ownership concentration was shown by Reference [5] to have a positive but insignificant relationship with audit quality.

The establishment of an effective corporate governance system which can be fulfilled in the light of interaction between corporate governance external (audit) and internal (concentrated ownership) control mechanisms will effectively align the interests of management and shareholders towards the same goal [6] and increase the organization's performance and growth [7]. The quest for external audit services has its foundation in the principalagent conflicts which is due to the separation of management from ownership. In order to ensure that the financial statements so prepared by the management are credible and reliable for various stakeholders' use, it is legally required that such statements be subjected to external scrutiny by independent professional auditors. The presentation of an audit report that is of high quality therefore is perceived to enhance confidence in such report. Considering auditors as an external tool of corporate governance, the external they make sure that the annual accounts tabled before the management and investors (board of directors and shareholders) are reliable and accurate [8]. Consequently, the present study investigated the impact of ownership concentration on the audit quality of the firms listed on the Nigerian Stock Exchange.

\section{LITERATURE REVIEW}

\section{A. Conceptual Framework}

\section{1) Concentrated Ownership}

Ownership concentration represents the percentage of stockholding by the largest shareholders. The beneficial effect of ownership concentration is that it puts the managers on the monitoring radar of the majority shareholders thereby compelling them to make value maximizing decisions that are beneficial to the entire organisations. In the works of references [9]; [10], 
ownership concentration can provide an effective monitoring system which can minimize the maximization of managerial utility and hence bring about positive performance, this is otherwise known as monitoring hypothesis.

Contrary to this is expropriation hypothesis, which is enunciated in the study of reference [11]; they opine that ownership concentration can stifle managerial initiatives to acquire information especially in the face of uncertainty; whereas, reference [12] viewed dispersed ownership as possessing the capacity to provide such powerful incentives to managerial initiatives. Nonetheless, a foremost contention about ownership concentration as given by reference [13] indicates that the structure accords the major shareholders copious unrestricted influences over the use of companies' scarce resources in manners that are self-serving to the detriment of minority shareholders. In summary, the impact of concentrated ownership on firms' specific economic variables is anticipated to be of two folds. Concentrated ownership increase from the lowest percentage might assist in solving the common problem among owners, thereby increasing its positive effect on the entire organisation. A negative impact may be induced with a further ownership concentration increase because it may bring down the restraint from other stakeholders on tunneling. The effect becomes positive again as ownership concentration moves towards one hundred percent, as a result of reduction in the incentive for tunneling to the largest shareholders [14].

\section{2) Audit Quality}

In order to meet the needs of users of financial information; such information should be reliable, timely and relevant. This will give the users the assurance that the information can be trustworthy [15]. The expression of a professional independent opinion on the financial statement by the auditors is the primary objective of an audit exercise. The opinion is predicated on the availability of adequate and suitable audit evidence as to the conviction that the information presented in the financial reports is not materially misstated. In order for independent audit to achieve this objective, the audited financial reports users need to have assurance that the audit exercise has been carried out in accordance with relevant standards and that "a quality audit" has been achieved. According to reference [16] audit quality would include a rigorous audit, with an appropriate degree of professional skepticism, conducted in compliance with the applicable standards. Other essential elements might include depth of industry knowledge, the nature and extent of valuable insights and observations arising from the audit process or the ability to effectively coordinate services from many locations around the world.

From this definition, quality audit involves the significant fundamentals that make a situation which optimizes the possibility that audit quality is performed consistently. Hence, the auditors are saddled with the responsibility of executing quality financial statements audits. Though, quality audit can be well realized in an atmosphere supported by suitable contributors to the supply chain of financial reporting [16]. Recently, a Framework which was developed by the International Auditing and Assurance Standards Board (IAASB) termed "Framework for Audit
Quality" was given credence by IFAC. The Framework comprises interconnected features which include inputs, interactions, contextual and outputs factors. These factors are referred to as the significant features necessary for contributing to superior audit quality. First, the input attributes are more connected to the qualities which include the values; attitudes; ethics; knowledge and experience of the external auditors which also include the audit process effectiveness and the procedures of quality control. Secondly, interaction factor involves the interface amongst the important stakeholders, because the manner in which the stakeholders interrelate can have a specific influence on the quality of audit. These interfaces, so explained, can pave the way for a vibrant association between the inputs and outputs. The third factor (contextual factors), which include, legislations and regulations are believed to be important in achieving high quality audit in such a manner that they may influence the efficiency of the audit process. Finally, in relation to the output factors, the report of the auditors is the main output, which may add to the achievement of quality audit.

\section{B. Theoretical Framework}

\section{1) Stakeholder theory}

Stakeholder theory is an off shoot of the agency theory. Stakeholder theory proponents opine that executive directors should take adequate care of the shareholders' interest. Nonetheless, the contracted attention on shareholders has been criticized $[17 ; 18]$ thereby necessitating the expectation that directors should equally consider the stakes of many other differing interest parties, as well as those associated with environmental, ethical and social concerns. The change in the responsibility of the directors has brought about the improvement of stakeholder theory. According to reference [19], stakeholder theory apologists perceive that companies and society are interdependent and therefore the corporation serves a broader social purpose than its responsibilities to shareholders. Similarly, one of the initial supporters of stakeholder theory opined that "stakeholder is any group or individual who can affect or is affected by the achievement of the organisation's objectives" [20].

There exists substantial discuss amongst academics on a broad and narrow perspective of a firm's stakeholder. The definition by reference [20] cited above presented a wider coverage of stakeholders of a large number of bodies and comprises virtually every type of stakeholders. Contrarily, reference [21] proposed a contracted opinion, signifying voluntary stakeholders bear some form of risk as a result of having invested some form of capital, human or financial, or something of value, in a firm. Involuntary stakeholders are placed at risk as a result of a firm's activities. But without the element of risk there is no stake. The use of peril affords investors a valid right on the decisions been made by the firm, irrespective of their authority to effect changes in the organisation. According to reference [17] stakeholders are persons or groups with legitimate interests in procedural and/or substantive aspects of corporate activity. Based on the foregoing, this study is anchored on stakeholder theory because, every interest group is desirous of appropriate and reliable financial reports upon which their economic decisions can be based. The credibility and reliability of 
such reports can only be guaranteed by a quality audit report which concentrated ownership structure is expected to enhance.

\section{Empirical Review}

\section{1) Concentrated Ownership and audit quality}

Concentrated shareholders and external directors regarded as outside monitors exhibit significant responsibility in internal corporate governance structure setting. Whereas the costs of monitoring managers may be too exorbitant to the minority shareholders, investors with concentrated shareholding possess a motivation to exert control over the management, probably adding to an improved corporate value through the control measures required for management decision making [22]. Several studies have examined the impact of ownership concentration on audit quality, however, their findings varied. The effect of ownership concentration on quality of the listed firms in Malaysia was assessed by reference [23]. The study exhibited a significant and positive effect of ownership concentration on quality of audit.

Reference [22] investigated the impact of ownership block-holding on quality of audit of Nigerian listed manufacturing firms employing logistic regression model for the analysis and hypotheses hypothesis testing. The extracted data from published and audited financial statements represents that of 32 firms from the total of 59 firms. The study concluded that audit quality is positive and significantly affected by ownership through block holding. This means that ownership through block-holding influences audit quality positively. In the same vein, the impact of the mechanisms of corporate governance on audit quality in Iran was studied by reference [24] using a sample of 94 Iranian quoted companies on TSE from 2008 to 2012 was used. The regression result revealed that audit quality is positively and significantly affected by concentrated and institutional ownership. Reference [1] investigated the association between concentrated ownership and auditing fees of Tehran Stock Exchange quoted companies. 114 listed companies from 2007 to 2012 were used as a sample. Descriptive correlation based on panel data was used in analyzing the data, the results showed that the correlation between institutional ownership, concentration and auditors fee is negative. Reference [25] investigated concentrated ownership and auditors' fees in Bangladesh. A negative and significant association was established which implies that lesser audit fees were paid by companies when such companies are controlled by institutional shareholders.

\section{RESEARCH METHOdOLOGY}

In this paper, the impact of concentrated ownership on audit quality of Nigerian listed manufacturing firms using experimental research design was examined. With the aid of non-probability sampling technique, the sample size of 36 listed manufacturing companies was selected from a population of 185 companies. The study used secondary data extracted from the published audited annual financial statements of the firms under consideration covering a period 2007 to 2017 .

\section{A. Definition and Measurement of Variables}

In this present study, concentrated ownership represents the independent variable while audit quality is the dependent variable. Auditors' tenure was employed as the proxy for audit quality while firm size (FSize) and financial leverage (FLev) were used as control variables measures.

Concentrated Ownership: Concentrated ownership is a feature that provides legal protection to minority shareholders of the companies [26]. This is the percentage of the shareholding owned by a given number of majority investors. For the purpose of this study, ownership concentration was calculated as the overall percentage of investors who have holding of more than five percent $(5 \%)$ of the total issued shares of the companies $[8 ; 5 ; 7 ; 1]$.

Auditors' Tenure: According to reference [27], auditors' tenure is the span of the engagement of the audit firm and by the client. Extremely extended acquaintance of auditors with the clients' firms may compromise auditors' independence [28]. According to reference [29], audit quality in relation to auditors' tenure was measured using the years of engagement as auditor to the firms under consideration. If the tenure is 5 years and above, we assigned 1, otherwise 0 .

Firm Size: The choice of firm size as a control variable is in line with the empirical studies conducted by reference [30] who posited that firm size is significantly associated with auditor preference. Companies firm size for the purpose of this study was determined the calculation of total assets' natural logarithm.

Financial Leverage: Financial leverage is associated to the extent to which a firm is geared and it is touted as a major internal governance mechanism aimed at mitigating agency costs. This study used the percentage of the totality of liabilities to entire assets to measure the financial gearing of the firms under consideration.

\section{B. Method of Analysis}

This study used panel data methodology for estimation while regressions were employed to analyse and test the hypothesis. The following model of reference [31] was adapted in order analyze our data:

$$
\mathrm{AQ}=\alpha+\beta 1 \mathrm{OC}+\beta 2 \mathrm{FO}+\beta 3 \mathrm{IO}+\beta 4 \mathrm{SI}+\beta 5 \mathrm{LE}+\mathrm{e}
$$

Where: AQ is audit quality; OC represents ownership; FO stands for foreign ownership; IO is institutional ownership; SI represents company size and LE means leverage.

\section{1) Implicit Model}

The following model was formulated for the purpose of this study

$$
\begin{aligned}
& \text { AQit }=\alpha i t+\beta 3 \text { C-ownit }+\beta 5 \text { Fsizeit }+\beta 6 \text { Flevit }+ \text { eit-------- } \\
& --(1)
\end{aligned}
$$

\section{2) Explicit Model}

AUDitit $=\alpha$ it $+\beta 3$ C-ownit $+\beta 5$ Fsizeit $+\beta 6$ Flevit + eit -$-(2)$

Where, AUDit represents audit tenure (measure of dependent variable) while the explanatory variable is concentrated ownership (C-own). Firm size (Fsize) and financial leverage (Flev) represent mediating variables. The 
$\alpha$ and $\beta$ are the coefficients of the variables and subscripts $i$ and $t$ connotes each quoted firm at time $t(2007 \ldots \ldots .2017)$.

\section{Data Analysis}

This section contains the descriptive analysis of concentrated ownership and audit quality metric which similarly indicates inter-relationship among them. The study period of the analysis is from 2007 to 2017. In Table 1, the number of observations, mean, median, maximum, minimum and standard deviation of each of the dependent and independent variables are presented. The table shows two categories of variables.

\section{1) Auditor's Tenure (AUDit)}

Similar to Audit Size, Auditor's Tenure (AUDit) 1 has a least value of 0 and an extreme value of 1 . These figures imply that the indicator is truly a dummy variable with the value of one (1) where services of an external auditor are engaged more than three (3) years consecutively during the period under review and zero (0) otherwise. Moreover, the average value of Audit tenure is 0.81 suggesting that the services of certain external auditors are engaged more than three (3) consecutive years mostly during the period.

\section{2) Concentrated Ownership (C-own)}

Ownership concentration as shown in Table 1 has a least value of 0.00 and a extreme value of 0.96 with a Standard deviation of 0.22 . These show that the proportion of share owned by the substantial shareholders ranged between $0.00 \%$ and $96.0 \%$. Correspondingly, the average value of Cown is 0.55 and the median value is 0.60 suggesting that on average, the proportion of share owned by substantial shareholder is $55.0 \%$ of the entire share and the value relatively varies.

\section{3) Firm Size (F-Size)}

The natural logarithm of the total asset is computed to determine the firm size. As shown Table 1, the average and median values of F-size are found to be 15.81 and 15.77 respectively. These indicate that the firms are relatively similar in terms of size. In addition, the minimum and maximum values of 11.13 and 20.10 with a Standard deviation value of 2.02 further confirmed that during the period, all the firms' asset do not vary much.

\section{4) Firm Leverage (Flev)}

This is measured as the ratio of total liabilities to total assets. This shows the ability of a firm to pay out debt from its total asset. The mean value of Flev is $1.01 \%$ while the median value was $0.56 \%$ indicating that the total debt to asset ratio is $101.0 \%$ on average and that the debt is about $56 \%$ (approximately) of the firms' asset during the period in terms of middle value. In addition, the results show that these ratios among the firm relatively vary. The minimum and maximum values of 0.00 and 22.06 with a Standard deviation value of about 2.42 show that during the period, one of the firms' assets is as low as $0 \%$.

\section{TABLE 1: SUMMARY STATISTICS}

\begin{tabular}{lcccccc}
\hline \hline Obsns & Mean & Median & Maximum & Minimum & $\begin{array}{c}\text { Std. } \\
\text { Dev. }\end{array}$ \\
\hline \multicolumn{7}{c}{ Dependent Variable } \\
\hline AUDit & 396 & 0.81 & 1.00 & 1.00 & 0.00 & 0.39 \\
\hline \hline
\end{tabular}

\begin{tabular}{lcccccc}
\hline \hline \multicolumn{7}{c}{ Independent Variable } \\
\hline $\begin{array}{l}\text { C- } \\
\text { own }\end{array}$ & 396 & 0.55 & 0.60 & 0.96 & 0.00 & 0.22 \\
\hline F-size & 396 & 15.81 & 15.77 & 20.10 & 11.13 & 2.02 \\
\hline Flev & 396 & 1.01 & 0.56 & 22.06 & 0.00 & 2.42 \\
\hline \hline
\end{tabular}

Source: Author's Computation (2019), Note: Auditor's Tenure (Audit), Concentrated ownership (C-own); and Firm size (Fsize) and Financial leverage (Flev) are mediating variables

\section{Pearson Pairwise Correlation}

The result of correlation analysis which shows the degree of correlation among the selected variables in this study as part of the preliminary analysis is presented. The reason for this examination is to guarantee that the associations amongst the explanatory variables are not to the extreme to the level of causing problems of multicollinearity. According to the result in Table 2, However there were existence of negative association between Auditor's Tenure (AUDit), Financial leverage (Flev) and Audit Fees (AUDif) with the correlation coefficients $r=-0.021, r=-0.465$ and $r$ $=-0.181$ respectively. Focusing on the associations between Audit Size (AUDis) and the rest of the variables, the correlation coefficients of $r=0.080, r=0.315, r=0.058, r=$ 0.192 and $r=0.521$ indicate that Auditor's Tenure (AUDit), Foreign ownership (F-own), Concentrated ownership (Cown), Institutional ownership (I-own) and Firm size (Fsize) maintained positive associations with Audit Size (Audis) while Managerial ownership (M-own), Financial leverage (Flev) maintained negative associations with Audit Size (Audis) with the correlations coefficients $r=-0.358$ and $r=-$ 0.201 . Considering the associations between Auditor's Tenure (AUDit) and the rest of the variables, the result shows that there are existences of positive associations between firm size (Fsize), Financial leverage (Flev), and Auditor's Tenure (AUDit) as can be seen from the correlation coefficients of $r=0.004$ and $r=0.012$ respectively. However, a negative association is reported between audit tenure (AUDit) and concentrated ownership (C-own) with a correlation coefficient of -0.036 . Precisely, there is no correlation coefficient that is too high to the point of causing multicolinearity problem.

\section{TABLE 2: CORRELATION MATRIX}

\begin{tabular}{lcccc}
\hline \hline Correlation & AUDit & C-own & F-size & Flev \\
\hline AUDit & 1 & & & \\
\hline C-own & -0.036 & 1 & & \\
\hline F-size & 0.004 & 0.305 & 1 & 1 \\
\hline Flev & 0.012 & -0.005 & -0.333 & \\
\hline \hline
\end{tabular}

Source: Author's Computation (2019), Note: Auditor's Tenure (Audit), Concentrated ownership (C-own); and Firm size (Fsize) and Financial leverage (Flev) are mediating variables 


\section{E. Regression Results and Discussion of Findings}

The regression analysis was conducted using Pooled, random and fixed effect models which are the fundamental estimators of data that is panel in nature. In arriving at a better models' parameter, Breusch and Pagan Lagrangian multiplier test was conducted in order to choose between a random and pooled effect models. The test result for pooled and random effect model as presented in Table 3 is statistically significant implying non-acceptance of the null hypothesis. Hence, the most appropriate model is random effect model. However, based on the result of LM; the study also conducted Hausman specification test which is also statistically significant suggesting the non-acceptance of the null hypothesis. These show that that the available data is not poolable and that random effect model is not appropriate for this purpose; rather fixed effect model is appropriate. Therefore, the fixed effect model results were interpreted in this study.

TABle 3: BReusch AND PAgAn LAGRANGe MultiPlieR AND HAUSMAN TEST FOR AUDITOR's TENURE

\begin{tabular}{ccc}
\hline \hline Tests & $\begin{array}{c}\text { Breusch-Pagan } \\
\text { Lagrange } \\
\text { Multiplier (LM) }\end{array}$ & Hausman test \\
Chi2 & 4.417 & 16.81 \\
\hline P-Value & 0.036 & 0.002 \\
\hline \hline
\end{tabular}

Source: Author's Computation (2019), Note: Auditor's Tenure (Audit), Concentrated ownership (C-own); and Firm size (Fsize) and Financial leverage (Flev) are mediating variables.

Concentrated Ownership and Auditor's Tenure (AUDit)

AUDitit $=1.938-0.133$ C-ownit -0.067 Fsizeit + 0.013Flevit + eit

In this section, the regression result on the impact of ownership concentration on audit quality of listed manufacturing companies in Nigeria in terms of auditor's tenure (AUDit) is presented. According to the result in Table 4 , the significant $\mathrm{F}$-statistics value $(\mathrm{F}=1.691 ; \mathrm{P}$ value $=0.007]$ shows that the fixed effect model statistically significant. The coefficient of determination (R2) value which is 0.164 implies that the explanatory variables account for about $16.4 \%$ variations that occur in the dependent variable (auditors' tenure). Considering this result, concentrated ownership (C-own) coefficient has a negative and insignificant coefficient $(\beta=-0.133$; $\mathrm{P}$-value $=$ $0.689)$. The insignificant result suggests that the impact of concentrated ownership (C-own) on audit quality of the selected firms in terms of auditor's tenure (AUDit) is insignificant while the negative sign connotes that a unit increase in concentrated ownership will cause a 0.133 decrease in audit quality as measured by auditors' tenure. For firm size (Fsize), the coefficient is seen to be insignificant $(\beta=-0.067 ; \mathrm{P}-$ value $=0.189)$; again, the negative and insignificant result suggests that the effect of firm size (Fsize) on audit quality of the selected firms in terms of auditor's tenure (AUDit) is insignificant just like that of audit size (AUDis). The coefficient ( $\beta=0.013 ; p=$ 0.415 ) of financial leverage (Flev) shows a positive but insignificant association with audit quality in terms of auditor's tenure (AUDit). Therefore, the insignificant result suggests that the effect of financial leverage (Flev) on Audit quality of the selected firms in terms of auditor's tenure (Audit) is insignificant.

TABLE 4: REgRESSION RESUlt OF AUdITOR'S TENURE

\begin{tabular}{|c|c|c|c|}
\hline Variable & PED & RAM & FID \\
\hline C_OWN & $\begin{array}{c}0.044 \\
(0.224) \\
{[0.843]} \\
\end{array}$ & $\begin{array}{c}0.001 \\
(0.258) \\
{[0.997]} \\
\end{array}$ & $\begin{array}{l}-0.133 \\
(0.332) \\
{[0.689]}\end{array}$ \\
\hline F_SIZE & $\begin{array}{c}0.005 \\
(0.013) \\
{[0.720]} \\
\end{array}$ & $\begin{array}{c}0.002 \\
(0.018) \\
{[0.893]} \\
\end{array}$ & $\begin{array}{l}-0.067 \\
(0.051) \\
{[0.189]} \\
\end{array}$ \\
\hline FLEV & $\begin{array}{c}0.001 \\
(0.01) \\
{[0.962]}\end{array}$ & $\begin{array}{c}0.004 \\
(0.012) \\
{[0.713]} \\
\end{array}$ & $\begin{array}{c}0.013 \\
(0.016) \\
{[0.415]} \\
\end{array}$ \\
\hline$C$ & $\begin{array}{c}0.756 \text { *** } \\
(0.191) \\
{[0.000]}\end{array}$ & $\begin{array}{c}0.806^{* * * *} \\
(0.264) \\
{[0.002]}\end{array}$ & $\begin{array}{l}1.938 * * \\
(0.772) \\
{[0.013]} \\
\end{array}$ \\
\hline Observations & 396 & 396 & 396 \\
\hline$R^{2}$ & 0.017 & 0.013 & 0.164 \\
\hline $\operatorname{Adj.} R^{2}$ & 0.002 & -0.002 & 0.067 \\
\hline F-Statistic & 1.140 & 0.846 & 1.691 \\
\hline Prob. (F-Stat.) & 0.338 & 0.535 & 0.007 \\
\hline
\end{tabular}

Source: Author's Computation (2019),). Note: The dependent variable is Auditor's Tenure (Audit). The Independent variable is concentrated ownership (C-own) and Firm size (Fsize) and Financial leverage (Flev) are mediating variables; Standard deviation( ), Probability [ ]. *** $\mathrm{p}<0.01$, $* * \mathrm{p}<0.05, * \mathrm{p}<0.1$

\section{F. Diagnostic Tests for Auditor's Tenure}

Also, this study used Jarque-Bera statistic to check whether the error term of the estimated model when the auditor's tenure is regressed on concentrated ownership is normally distributed. From Figure 1, the test statistics and its associated p-value is statistically insignificant. These mean that the residual is normally distributed. For heteroskedasticity, the study used heteroskedasticity consisted standard error, hence the test for constant variance is not required.

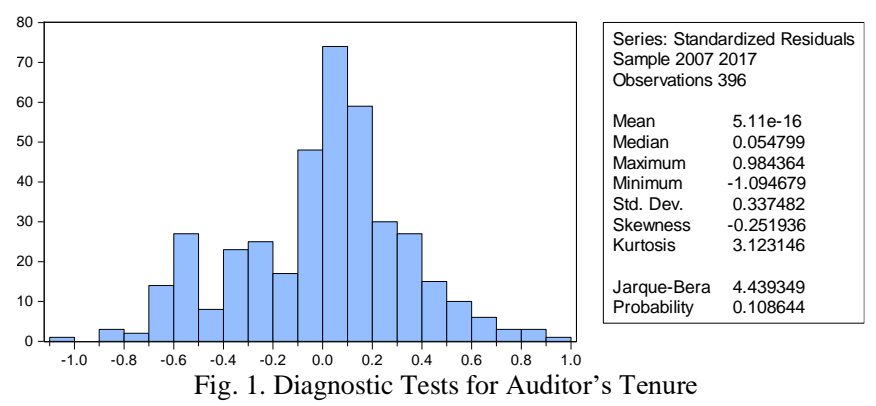

IV. CONCLUSION AND RECOMMENDATIONS

The main focus of this study was the examination of the impact of concentrated ownership on audit quality metric of auditors' tenure from 2007 to 2017 employing descriptive, correlations and linear regression. After reviewing the relevant ownership structure extant literature and audit 
quality and analyzing data and hypothesis tested, the study concluded ownership concentration does not statistically and significantly impact audit quality as calculated by audit tenure. Based on the finding, the study recommends that ownership concentration should be maintained at a controllable level; the insignificant impact of concentrated ownership on auditors' tenure as evident in this study may be the result of inefficient monitoring by large owners. But when ownership concentration by large ownership is maintained at a controlling level, firm values and other performance parameters become positive which may be as a result of an effective internal control system against the expropriation of resources and exploitation of minority shareholders by large shareholders.

\section{REFERENCES}

[1] M. Yahyazadehfar, H. Shababi, and S.S. Hosseini, "Investigation of relationship between ownership concentration and auditing fees in listed firms of Tehran Stock Exchange," International Journal of Management, Accounting and Economics, vol. 2, no. 8, pp. 891-901, 2015.

[2] S. Mitra, M. Hossain, and D. Deis, "The empirical relationship between ownership characteristics and audit fees," Review of Quantitative Finance and Accounting, vol. 28, pp. 257-285, 2007.

[3] A. Gomes, "Going public without governance: Managerial reputation effects," The Journal of Finance, vol. 55, no. 2, pp. 615-646, 2000.

[4] M. J. Niskanen, Karjalainen and J. Niskanen, "The role of auditing in small, private family firms: Is it about quality and credibility?," Family Business Review, vol. 23, no. 3, pp. 230-245, 2010.

[5] K. A. Al-Rawash, and S. Z. Alzeaideen, "The effect of ownership structure and corporate debt on audit quality: Evidence from Jordan," International Journal of Economics and Financial Issues, vol. 8 , no. 3, pp. 51-58, 2018.

[6] E. F, Fama, and M. C. Jensen, "Separation of ownership and control," Journal of Law and Economics, vol. 26, no. 2, pp. 327-349, 1983

[7] E. M. R. Sayedeh, S. Hamid and V. P. Hashem, "The impact of audit quality and ownership structure on earnings management on Tehran Stock Exchange," International Business Management, vol. 10, no. 10 , pp. 1827-1832, 2016.

[8] E. M. Al-Matari, Y. A. Al-Matari and S. A. Saif, "Ownership structure, audit quality and firm performance moderating and directeffect models: An empirical study," Corporate Board: Role, Duties and Composition, vol. 13, no. 1, pp. 28-35, 2017.

[9] A. A. Berle and G. C. Means, The modern corporation and private property, MacMillan publishing Co, New York, 1932.

[10] A. Shleifer and R. Vishny, "Large shareholders and corporate control," Journal of Political Economy, vol. 94, pp. 461-488, 1986.

[11] P. Aghion, and J. Tirole, "Formal real authority in organizations," Journal of Political Economics, vol. 105, no. 1, 1997.

[12] J. Cremer, "Arm's length," Quarterly Journal of Economics, 110, 1995.

[13] C. Bai, Q. Liu, J. Lu, F. M. Song and J. Zhang, "An empirical study of corporate governance and market valuation in China," Economic research journal, vol. 2, pp. 84-110, 2004.

[14] S. Johnson, R. La Porta, F. Lopez-de-Silanes and A. Shleifer, "Tunneling," American economic review, vol. 90, pp. 22- 27, 2000.

[15] International Auditing and Assurance Standards Board (IAASB). A framework for audit quality, key elements that create environment for audit quality. [Online]. Available: https://www.ifac.org 2014

[16] KPMG, "Audit point of view: What is audit quality," International Cooperative 1-2, 2016

[17] T. Donaldson and L. E. Preston, "The stakeholder theory of the corporation: concepts, evidence and implications," Academy of Management Review, vol. 20, no. 1, pp. 65-91, 1995.

[18] R. E. Freeman, A. C. Wicks and B. Parmar, "Stakeholder theory and the corporate objective revisited," Organization Science, vol. 15, no. 3, pp. 364-369, 2004 .

[19] G. Kiel and G. Nicholson, Boards that work: A new guide for directors, Sydney: McGraw Hill, 2003.

[20] R. E. Freeman, Strategic Management: A Stakeholder Approach, Boston: Pitman, 1984.
[21] P. Clarkson, "In recognition of dual relationships", Transactional Analysis Journal, vol. 24, no. 1, pp. 32-38, 1994

[22] S. O. Abu, T. Nyor, and J. Okpanachi, "Institutional ownership and Block hold ownership and audit quality of listed manufacturing firms in Nigeria," Journal of finance and Accounting, vol. 6, no. 1, pp. 15-26. 2018.

[23] M. A. Jusoh, A. Ahmad and B. Omar, "Managerial ownership, audit quality and firm performance in Malaysian," International Journal of Arts and Commerce, vol. 2, no. 10, pp. 45-58, 2013.

[24] I. Peyman, and L. Mina, "The effect of corporate governance mechanisms on auditing quality of firms accepted in Tehran Stock Exchange," Applied Mathematics in Engineering, Management and Technology, vol. 1, no. 3, pp. 58-63, 2013.

[25] A. Rahman Khan, D. Mahboob Hossain and J. Siddiqui, "Corporate ownership concentration and audit fees: The case of an emerging economy," Advances in Accounting, vol. 27, no. 1, pp. 125- 131, 2011.

[26] A. Sanda, A. S. Mikailu and T. Garba, "Corporate governance mechanisms and firm financial performance in Nigeria," AERC Research Paper 149, African economic research consortium, Nairobi, pp. 1-47, 2005.

[27] A. T. Babatolu, O. O. Aigienohuwa, and E. Uniamikogbo, “Auditor's independence and audit quality: A study of selected deposit money banks in Nigeria," International Journal of Finance and Accounting, vol. 5, no. 1, pp. 13-21, 2016.

[28] A. O. Okolie, "Audit Tenure, Audit Independence and Accrual-based Earnings Management of Quoted Companies in Nigeria," European Journal of Accounting Auditing and Finance Research., vol. 2, no. 2 , pp. 63-90, 2014.

[29] S. I. Adeniyi and L. G. Mieseigha, "Audit tenure: An assessment of its effects on audit quality in Nigeria," International Journal of Academic Research in Accounting, Finance and Management Science, vol. 3, no. 3, pp. 275-283, 2014.

[30] M. L. Defond, "The association between changes in client firm agency cost and auditor switching," Auditing, vol. 11, no. 16 1992.

[31] Q. Zureigat, "The effect of ownership structure on audit quality: Evidence from Jordan," International Journal of Business Social Science, vol. 2 , no. 10, pp. 38-46, 2011. 